$1-1-1957$

\title{
Some effects of location on West Virginia nurseries marketing ornamental plants
}

Roger W. Pease

Follow this and additional works at: https://researchrepository.wvu.edu/ wv_agricultural_and_forestry_experiment_station_bulletins

\section{Digital Commons Citation}

Pease, Roger W., "Some effects of location on West Virginia nurseries marketing ornamental plants" (1957). West Virginia Agricultural and Forestry Experiment Station Bulletins. 394.

https://researchrepository.wvu.edu/wv_agricultural_and_forestry_experiment_station_bulletins/380 @ WVU. It has been accepted for inclusion in West Virginia Agricultural and Forestry Experiment Station Bulletins by an authorized administrator of The Research Repository @ WVU. For more information, please contact ian.harmon@mail.wvu.edu. 


\section{Some Effects of Location on West Virginia Nurseries Marketing Ornamental Plants}

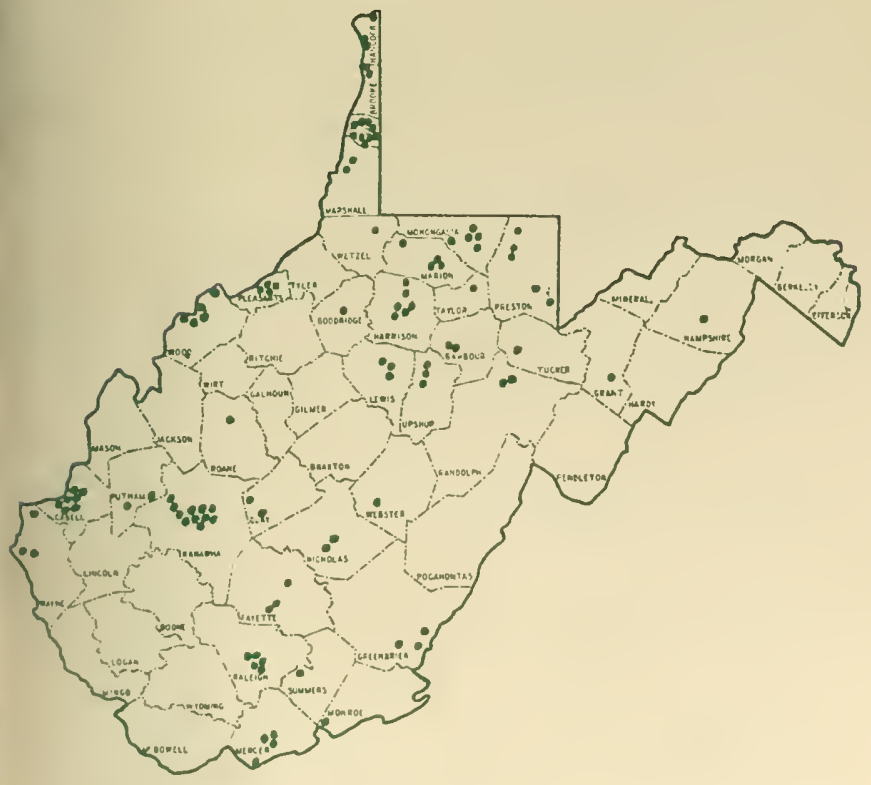




\section{ACKNOWLEDGMENT}

The author wishes to acknowledge the cooperation of Mr. F. Waldo Craig, State Entomologist, and of the Ornamentals Nurscrymen of W'est Virginia.

\section{THE AUTHOR}

Roger W. Pease, author of Some Effects of Location on W'est Virginia Nurseries Marketing Ornamental Plants, is Assistant Agricultural Economist in the West Virginia University Agricultural Experiment Station.

WEST VIRGINIA UNIVERSITY

Agricultural Expleriment Station

College of Agriculture, Forestry, and Home Economics

H. R. VARNEY, DiRECTOR

MORGANTOWN 


\section{Some Effects of Location on West Virginia Nurseries Marketing Ornamental Plants}

\section{Introduction}

ROGER W. PEASE

N 1955 the West Virginia University Agricultural Experiment Station made its first survey of nurseries specializing in woody ornamental plants. Data from it have furnished material for determining some probable effects of locality on marketing nursery products and services under IVest Virginia conditions.

Conditions existing in this State may not be indicative of conditions elsewhere, and there are so few nurseries and cities in WVest Virginia that the conclusions drawn in this bulletin are subject to further verification.

\section{Definitions}

To avoid confusion, definitions of some terms used are given below: Where feasible, these definitions correspond to those followed by the State Department of Agriculture.

Ornamentals Nursery: A concern growing and selling for giving tway) any nursery crops customarily used to provide shade or to beautify premises. The term ornamentals nursery will be condensed to nursery' for the sake of brevity.

Christmas Tree Nursery: A concern growing and selling (or giving iway) live Christmas trees to be used later as transplants.

Christmas Tree Plantation: A concern growing Christmas trees and selling (or giving away) cut trees only. A Christmas trce plantaion is not considered a nursery by the State Department of Agriculture and docs not register an such in West Virginia. If a Christmas tree planation sells (or gives away) any live Christmas trees, it is reclassified as 1 Christmas tree nursery.

Services: Landscaping; tree surgery and care; planting and (or) naintaining grounds, gardens, and ornamcrutal plants.

Full-Time Nursery: An ornamentals nursery using the full-time se1ices of at least one man throughout the growing scason (at least ninc nonths). The owner may or may not engage in other occupations. 
Part-Tine Nursery: An ornamentals nursery not using the fulltime services of at least one man throughout the growing season.

Type A Nusery: * I full-tinc ornamentals nursery linanced by, or incidental to, sone enterprise other than the performance of services.

Type B Nursery: A full-time ormamentals nursery financed by, or incidential to, the performance of services.

New Nursery: A full-tinc ormanentals mursery which, as of 1954 , had been registered for less than six years with the State Department of Agriculture. A new mursery may be either Type $A$ or Type $B$.

Established Nurscry: A full-time ormamentals nursery which, a: of 195.1, had been registered for more than ten years with the State De partment of Agriculture.

\section{Scope of the Survey}

Neither Christnas tree plantations nor Christmas tree nurseries wer included in the Agricultural Experiment Station survey because th Christmas trec and ormamentals industries are dissinilar. The Christma tree industry markets primarily dead, cut trees; the orntmentals industr markets living shrubs and trees, with roots intact. 1)ifferent soil require ments, marketing metlods, and cultural practices are involved. Nurserie also were cxcluded if they handled only plants which customarily ar used for the production of edible fruit or unts.

Of the I7.1 nurseries registered with the State 1)epartment of $\mathrm{Agr}$. culture in 195.1, 59 wcre excluded, and information could not be obtaine from cight others which lor various reasons latd discontimed operation Ol the 59 excluded from the survey, 30) were registcred as Christmas tre nurseries; 18, when interviewed, were found to have handled only Chris mals trees in 195.1; and cleven were registered as handling only berries c intt trees.

\section{Location of Nurseries}

Figure 1 shows the approximate locations of the 107 nurseries su veyed. It divictes the State arbitrarily into five general areas, the ut shaded sections representing areas where nurseries are concentrate Fifty-nine nurseries were located in Area 1; and Tyter was the on county in that area which did not contain a uursery. Forty-four nu series were in Area II, a belt of twelve counties crossing the souther part of West Virginia. Two nurseries were located in Area III, compose

- A complete classitieution of nurscries is not used in this huljetin. 


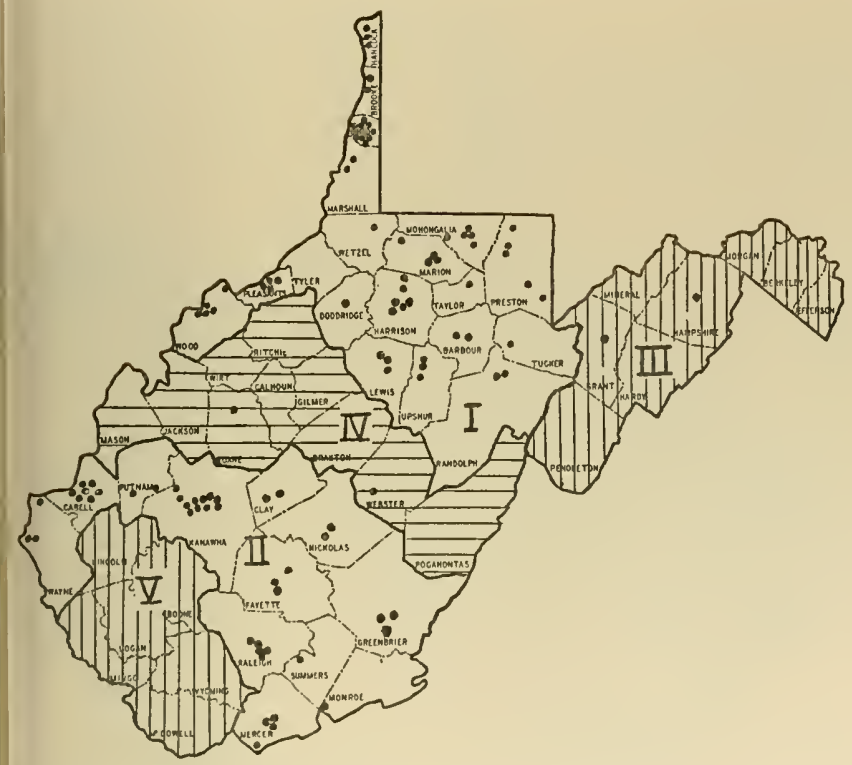

IGURE 1. Location of West Virginia ornamentals nurseries.

If eight counties in or near the Eastern Panhandle; and two were in Irea IV, a band of ten counties stretching east and west across the cener of the State. A block of six counties in the southwest, comprising irea $V$, contained no nurseries.

\section{ull-Time and Part-Time Nurseries}

When nurseries were divided into full-time and part-time operaions, ${ }^{1} 51$ qualified as full-time cnterprises, and 56 were part-time. In 954 the full-time concerns reported sales which averaged 6,2:14 plants, xclusive of rooted cuttings and lining-out stock (young plants ready to e set in nursery rows). As many sold more than 2,000 plants as sold less zan 2,000. On the other hand, the average sale for part-time nurseries as 254 plants, and as many sold less than 63 as sold more. The 51 fullme concerns sold 318,420 plants, exclusive of rooted cuttings and lin- 


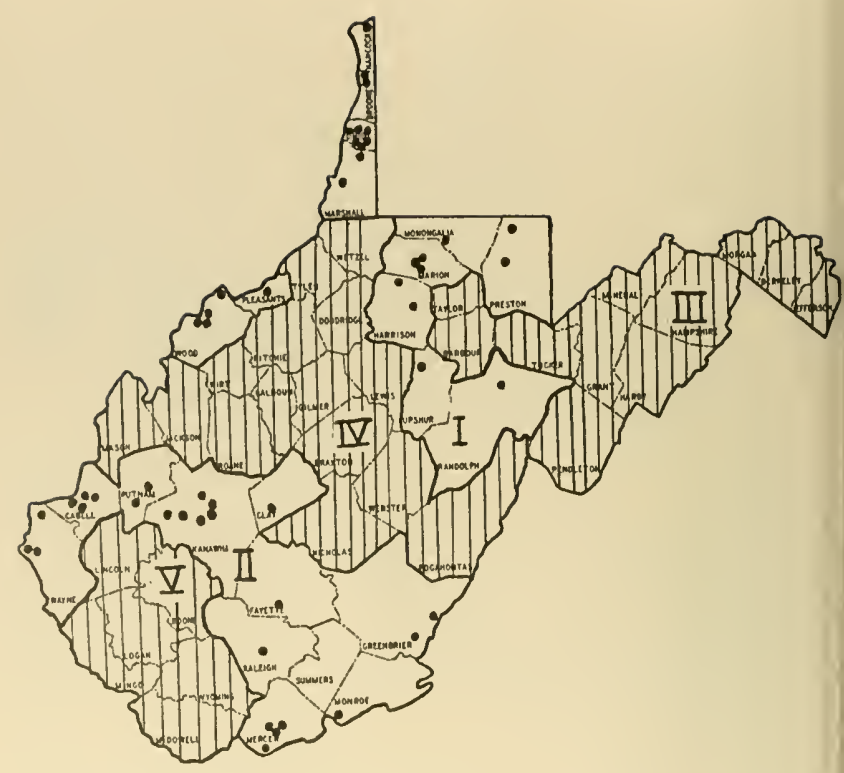

FIGURE 2. Location of full-time nurseries in West Virginia.

ing-out stock, a volume more than 20 times as great as the 14,228 plan sold by the 56 part-time nurseries. These figures include both wholesa and retail sales. ${ }^{2}$

Only two owners of full-time nurseries reported that they had fu tiue employment elsewhere. Among the operators of part-tine concer all of the men had employment in other occupations, and thr women divided their time between homenaking and their nurseries.

Part-time concerns may have been handicapped by at least thr apparent factors: much of the owners' working time was spent in oth occupations; the nurseries were not worked on a regular, eight-hour bas and the owners' places of employment usually restricted freedom choice in locating nursery projects. Under these circumstances it wou be difficult to determine favorable or unfavorable characteristics of cation for part-time concerns; and therefore they will be excluded frc further study in this report.

:Complled from sales data reported by nurserymen for the year 1954 


\section{Location of Full-Time Nurseries}

Figure 2 shows the approximate locations of the State's 51 full-time nurseries. Distribution approximates that previously shown in Figure 1. However, all of the nurserics lie within Areas I and II-the southern east-west belt, and the northern block of counties which now is split into three comparatively isolated sections.

\section{Four Factors of Location}

There are at least four factors of location which might be important to nurserymen in marketing ornamental nursery crops. First, it is possible that a location in the vicinity of a U. S. highway is advantageous to any nursery and vital to one concentrating on cash-and-carry sales derived from through traffic. Second, it might be vital that nursery sales-areas be on, or within sight of, paved highways, whether federal, primary, or secondary. Third, nurseries located in thickly populated sections, irrespective of large cities, might market at a distinct advantage. Fourth, a location in or near a comparatively large city might be important. An examination will be made of the State's lull-time nurseries in regard to these four characteristics, to discover if one or more of the characteristics have exerted apparently causal influences.

\section{US HIGHWAYS}

Figure 3 shows the State's U. S. highways in relation to its full-time nurseries and to the five general arcas shown in Figures 1 and 2. It is apparent that through-highways converge and intersect where nurseries cluster in Cabell, Kanawha, Ohio, Wood, Marion, and Mercer countics. However, as of the 1950 Census, the average population of these six counties was 105,101 , almost three times the average county population of the State; and at least one of the State's 10) latrgest cities is within each of these countics. The construction of hard-surface U. S. highways received its impetus after automobile traffic had become relatively impos tant, and heary traffic to and from centers of trade probably caused highways to converge. Dense populations, irrespective of large cities; and comparatively large cities, irrespective of thickly populated general areas, may have caused both the clustering of murseries and the convergence of U. S. highways. Therefore, it should not be assumed that the association of clustering nurseries and converging U. S. highways is a cause-andeffect relationship.

In West Virginia it is difficult to determine the importance of U. S. highways to nurseries which concentrate on cash-and-carry sales derived from through traffic. Probably such nurscries should lie outside of congested city traffic; their display areas should be conspicuon 


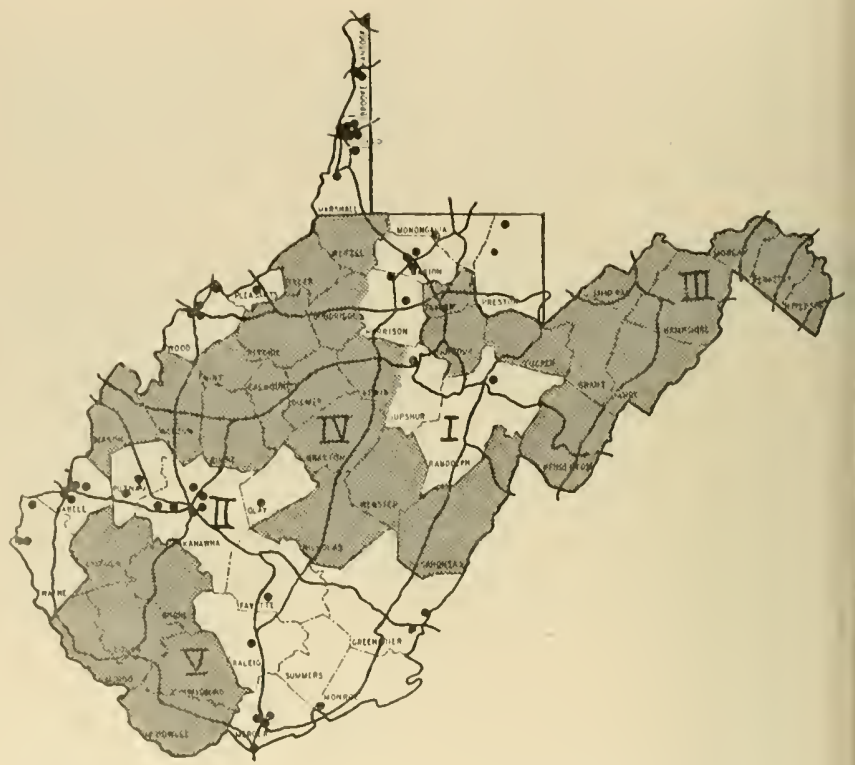

FIGURE 3. The relation of full-time nurseries and $U$. S. highways.

from several hundred fect along the highway; they should offer ample facilities for parking; and they should display ornamental plants in containers suited to kecp them undamaged during transportation over long distances. In 195.1 only two utreseries maintained cash-and-carry retail outlets which qualificd in all of these respects. One had been in operation only a year. It icported that its cash-and-carry sales were If per cent of its cotal retail sales, and of this 10 per cem the volume of sales derived from through traflic was unkown. The other qualified re tail outlet had been in operation six years. The owner reported that atbout 85 per cent of his total retail sales were made at the ontlet; bu (snly li) per cent of these were cash-and-carry. He conld not determin what percentage of the cash-and-carry sales had heen derived from through traffic.

\section{PAVED HIGHWAYS-FEDERAL, PRINARY, OR SECONDARY}

Although location on U. S. highways seems to have been incidenta rather than causal to the success of murseries, visibility of sales arcas fron 
pared highways of some kind might be important. However, 19 of the State's 51 full-time nurseries did not maintain their sales areas within sight of paved highways-federal, primary, or secondary; and four were located more than one mile from the nearest hard-surface road. The 19 nurseries whose sales areas were not visible from a highway sold almost 74,000 more plants than did the 32 nurserics whose sales areas were visible. The average numbers of plants sold retail by the two groups were almost identical, 2,685 and 2,635 respectively, but the wholesale average of the non-visible group was almost eight times as large as that for the visible group. In West Virginia it apparently is not vital that nursery sales areas be seen from paved highways.

\section{THICKLY POPULATED AREAS}

Location within thickly populated areas irrespective of large cities might be associated with the presence of nurseries.

In Figure 2 it was shown that Areas I and II contained all of the itate's full-time nurseries; but 10 cities with populations of more than $19,000^{3}$ also lay within these two areas, and three of the ten were cencors of the only urbanized areas in the State. ${ }^{3}$ After the total population of these cities and urbanized areas had been discarcled, the densities of population in Areas I and II were about 87 and 82 people per quare mile, respectively.

In Areas III and IV, where no nurseries were located, the populatiou lensitics wcre approximately 38 and $35^{3}$ people, respectively. Thus, he two areas containing all of the nurseries were more than twice as hickly settled, irrespective of large cities, as were the two areas lying vetween them and east of them.

In Area $\mathrm{V}$, the block of six southwestern counties, there were no ities with populations of more than 9,000:, but the density was $1 \mathrm{I}^{\text {* }}$ ersons per square mile. Thus, if the population of large cities is disounted, these six counties composed the most thickly settled sections of he Statc. However, they contained no uurseries.

If the various areas are contrasted on the basis of the numbers of wner-occupied homes per square mile, results are roughly similar. Areas and II, where all the nurseries are located, had approximately $1.3^{35}$ and 1" owner-occupied homes per square mile, but Areas III and IV had c'ss than half as many, approximately $6^{3}$ each. Area $V$ had ibout 10. IImost as many as Area II, but it containcd no uurseries.

Under West Virginia conditions, therefore, thickly populated areas, rrespective of large cities, may or may not be associated with the presruce of full-time nurseries. 


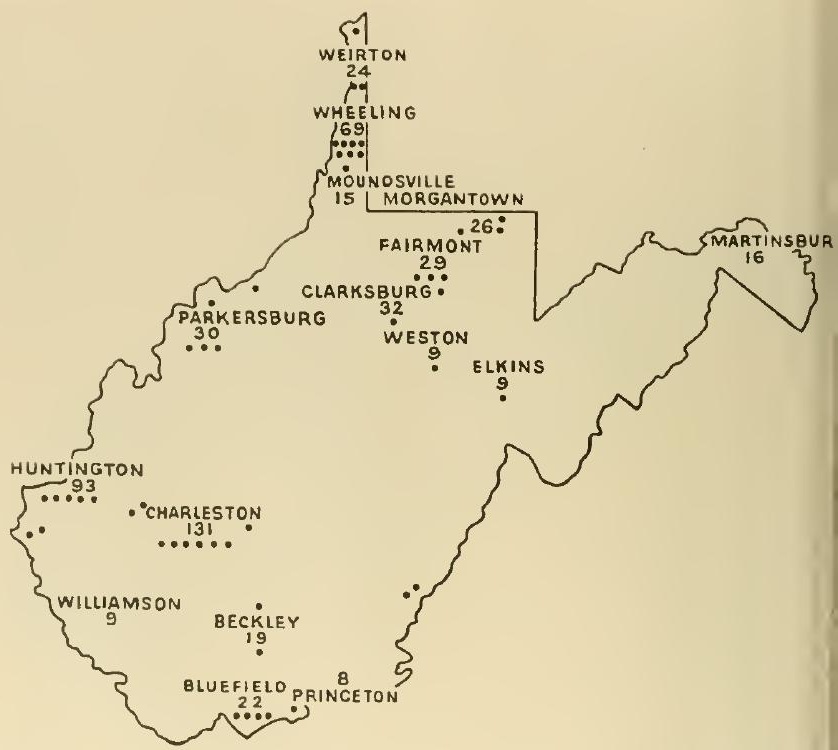

FIGURE 4. Relation of full-time nurseries to cities with $B, 000$ or more residen

Figure 4 shows the approximatc location of full-time nurseries relation to West Virginia cities with populations ol 8,000 or more, reported in the 1950 Census. IIt the case of Huntington, Charlestc and Wheeling, population figures for the urbanized areas were uss Populations are given ir thousmols, and muserics within or close city limits are shown clustering around the population figures. Calip were used to locate muscries ten miles or more from the centers of citi and these calipered distances ane consistently less than correspondi travel by road. Locations and calipered clistances were taken from 1 official West Virginia Highway map issued in 1952 by the State Rc Conmission.

In 195 there was at lcast me mursery within or close to each of 1 ten cities with populations of more than 19,000; but half of the six sm: er cities contained no nurseries and were close to none. The presence nurseries is associated in West Virginia with cities of 19,000 or $m$. residents but not necessarily with cities smaller than 19,000 . 


\section{Possible Service Areas}

To reduce investment costs and overhead expenses, and to obtain desirable soil and water conditions, it is probable that some nurserymen located their firms comparatively far from city limits. Those too far away may have failed or concentrated on wholesale marketing, whereas the more accessible concerns expanded their retail sales. Thus ornamentals service areas may have been determined by the success or failure of nurserymen. Large cities, served by extensive highway and utility systems, may have exerted broader service areas than did small cities.

\section{Adjusted City Populations}

The populations shown in Figure 4 misrepresent the relative sizes of the city areas listed. Figures for Huntington. Wheeling, and Charleston include both incorporated areas lying within the State and outlying West Virginia sections which are part of the urbanized areas. Because the 1950 Census gives no similar figures for cities with populations of less than 50,000, populations shown in Figure 4 for the other West Virginia cities include only incorporated areas.

Adjusted populations for the State's ten largest cities were prepared. The populations of Huntington, Wheeling, and Charleston were not changed, but in the case of the other cities, outlying incorporated or unincorporated places with 1,000 or more residents were included if they were within one mile of city limits. Distances, city limits, and outlying towns were taken from the State Roal Commission's map. The Census lists South Parkersburg as a separate, unincorporated town, but the Commission's may, names only Parkersburg. In the adjusted populations South Parkersburg and Parkersburg were combined because both were incorporated as Parkershurg after the 1950 Census had been completed.

\section{Projected Service Areas}

Possible service areas for the State's ten largest city artas were calculated. Outlying uurseries were located on the Road Conmission's map and distances lrom cities were measured by caliper. The locations of three nurseries calipered respectively, 55, 50 and 12 miles from the nearest large city. They were excluded from any projected service area. All other nurseries were within 30 miles of some central city, and only in the case of Huntington and Charleston were distances greater than 20 miles. Possible service areas scem to increase in size as the populations of central city areas grow larger.

Twelve population brackets were chosen, ranging from 20,000 (1) 140,000 , each bracker including a 10,0)0)-pepulation spread. For the 
first bracket a radius of 25 miles was alloted to a service area. Thi: radius was increased by five miles for bracket two, and for each subse quent bracket it was lengthened by half of the preceding increase. Deci mal fractions were carried to the nearest tenth.

Figure 5 shows adjusted population figures and projected servic areas. Weirton and Whecling; Morgantown, Fairmont, and Clarksburg overlap so extcusively that they will be considered hencelorth as exertin: only two scrvice areas-Wheeling and Clarksurg. Three nurseries la outside of any projected service area; and forty-eight, or more than 9 . per cent, lay within the seven projected areas. However, the areas wer calculated arbitrarily to fit existing conditions.

If the central cities have furnished common opportunities for num serymen starting in business; if these opportunities apparently were ir sufficient elsewhere; and if the three full-time nurseries lying outsid of any service area found substitutes for these opportunities, at leas two conclusions might be drawn: First, city arcas of more than 20,00

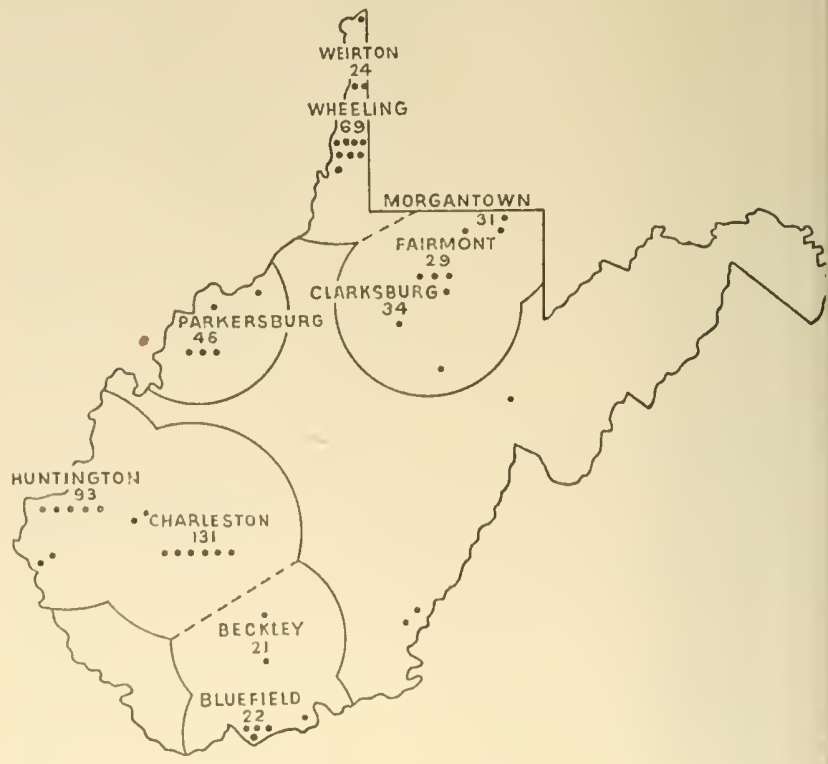

FIGURE 5. Adjusted population figures and projected zones of influence. 
apparently have exerted service areas which have offered opportunities important to the success of nurseries. Second, nurserics outside of these zones have developed and prospered without these opportunities. After examining the procedures of these outlying nurseries, other nurserymen might use successfully the same or similar practices in areas of West Virginia where there are no full-time nurseries at present.

\section{Services in City Areas Larger Than 20,000}

In 1954, eleven of the full-time nurseries within projected service ireas had been registered less than six years. Three belonged to Type 1, financed and established by enterprises other than services. They were excluded from further study. The other eight were Type B. Of hese, seven reported an average of 99.9 per cent reliance on services lor the sale of their nursery stock, and the eighth divided its sales between ervices and peddling. Apparently most new West Virginia nurserymen lepend on services both to provide income and to procure sales while heir nurseries are being started.

At the time of the survey, 60 per cent of the State's 23 established urserymen (registered more than ten years) had branched into wholcale marketing, and over 39 per cent maintained some form of specialized etail outlet. Yet they reported an average of more than 55 per cent eliance on services for retail sales. Only two did not rely on services. One of these sold his entire crop wholesale and the other operated his urrsery incidentally to an orchard.

Evidently it is not by chance that more than 94 per cent of the itate's full-time nurscries have centered around large citics, for these ities lrave furnished a common opportunity for performing services, oth to nurserymen starting in business without substantial capital back$\mathrm{ng}$ and to established nurserymen obtaining much of their income from ctail sales.

\section{jervices in Cities with Populations Smaller than 20,000}

There are no available data for determining the extent of service sportunities in West Virginia cities of varions sizes or the percentage of these opportunities which a new Type 13 nursery might expect to xploit. How many full-time nurseries have started and failed or become sart-time concerns also is unknown. In 1954, however, there were at least wo indications that in a small city service opportunitics have been inidequatc.

First: Only thrce of the State's full-time uurserics were located outside he service areas projected in Figure 5. Two were near a city with 2,64.3 esidents and the other close to one with 9,121. All three reported that 
their incones from the perfonmance of services were incidental to the rest of their nussery businesses; and the average of their reported retail sales was less than 6 per cent of the plants they sold. The other $9-1$ per cent was marketed wholesale. All three concerns belonged to Type $\Lambda$. Two were subsidiaries to larger nurseries, and the owner of the third had full-time employment in an enterprise other than the nursery business.

Second: Since 1930, as the populations of central city areas passed 20,000, nurseries appcared and survived. The 1940 Census reported that the combined populations of Beckley and its contignous town o Mabscott was 14,325 ; in 1950 their population reached 21,062. In 195 there were two full-tine nurseries within Beckley's projectel service area One had been in business live years and the other, lour. If a stead population increase is assumed, the population of Beckley's city are: reached about 20,298 in 1949, the year the first nursery appeared.

In 1930, Bluefield's population was 19,339; in 1940 it was 20,641. Ni West Virginia town larger than 1,000 is contiguous to Blucfield. In 195 lhe oldest Iull-time West Virginia nursery in the blueficld service are reported that it had bcen in business since 1938. If a steady increase i assumed, Bluefield's population reached 20,378 in that year.

In the Clarksburg service area the combined populations of Clark burg, Morgantown, and Fairmont passed 20,000 between 1900 and 1911 Parkersburg reaclued 20,000 in 1920; both Charleston and Huntingto in about 1908; and Wheeling soon after the Civil War. Data are nc available to show when the first successful full-time nurserics started $\mathrm{i}$ these five service areas.

\section{Nurseries Outside Projected Service Areas}

Trends of the past may not continue in the future, but circus stances which may cause trends to change often are disccrnible in th past. The three nurserie» which lie outside of any projected scrvi area may offer clues for future nurserymen. By affiliating with, or co tracting to, large established nurseries; by concentrating on wholesa marketing; by recognizing that services and retail sales probably will I incidental, if present at all. nuscrymen may find it feasible to locate areas of the State which are isolated Trom estalblished service areas. If : cheap land and labor, accessibility from a hard-surface road, desirable st and water conditions, and a climate favorable to specific ornament plants might become as important in determining the location of nurst ies as opportunities for performing services have been in the past. 


\section{Immary}

$\checkmark$ West Virginia, in 1954, there were no full-time nurseries in thickly populated areas that did not have at least one city whose incorporated area contained more than 19,000 people; and there was no apparent rrelation between location of sales areas within sight of highways and lumes of plants sold.

Ninety-four per cent of the State's full-time nurseries were clustered the general vicinities of cities whose incorporated and contiguous eas contained more than 20,000 people. New, full-time nurseries red almost exclusively on the performance of services for obtaining both tail sales and an income. Established nurseries procured more than If of their retail sales of plants by performing services in connection th these sales.

City areas of more than 20,000 seemed to offer service areas within ich service opportunities were adequate. Apparently service oppornities were inadequate in city areas smaller than 20,000; but a few irseries were prospering in remote locations by marketing wholesale $d$ by affiliating with large nurseries or operating incidentally to other terprises. 
